\title{
The Selective Vulnerability of Rice Root System Architecture to Organic and Inorganic Nitrogen
}

\author{
Jayeshkumar A. Bhabhor ${ }^{2}$, Kirti Bardhan ${ }^{1} *$, Dhiraj P. Patel ${ }^{3}$, \\ Ajay V. Narwade ${ }^{2}$ and Harshad N. Chatrola ${ }^{1}$ \\ ${ }^{1}$ Department of Basic Sciences and Humanities, ${ }^{3}$ Department of Natural Resource \\ Management, ASPEE College of Horticulture and Forestry, Navsari Agricultural University, \\ Navsari (Gujarat) 396450 India \\ ${ }^{2}$ Department of Genetics and Plant Breeding, N. M. College of Agriculture, Navsari \\ Agricultural University, Navsari (Gujarat) 396450 India \\ *Corresponding author
}

\section{Keywords}

Root system architecture, Root plasticity, Rice, Organic and inorganic nitrogen

Article Info

Accepted: 08 June 2018 Available Online: 10 July 2018

\section{A B S T R A C T}

$\mathrm{N}$ fertilizers and high yielding varieties were major drivers of the enormous increase in rice productivity during the past 50 years. Despite increasing food production higher nitrogen use also contributed in environmental pollution and Increasing consciousness of conservation of environment and mitigation of climate change brought a major shift in cultivation practices of major crops towards organic agriculture. An important issue regarding the acceptance of organic agriculture is the question of productivity. In addition to readily available ammonium and nitrate ions, the soil of organic agriculture can contain a wide range of organic nitrogen compounds such as peptides, proteins, free amino acids, amino sugars and nitrogen heterocyclic compounds. The root system architecture (RSA) features are of utmost importance for increasing nitrogen use efficiency of future climateresilient varieties. From a fundamental point of view, the influence of nitrogen on root development is still poorly understood. Modulating root architecture is a strategy that aims at developing crops that capture nutrients more efficiently and are thus suitable for sustainable agriculture with fewer fertilizer inputs. Our experiment aimed to study the responses of IR-28 root system architecture to the availability of different forms of nitrogen, including organic at seedling stage, so that we can understand up to what extent our current rice varieties, which are exclusively breed for intensive agriculture, are suitable for organic agriculture. From the experimental results it was indicated that root parameters viz. primary root length was significantly reduced due to the availability of nitrogen in nitrate and ammonia while increased with organic N. Main root angle was significantly increased with increasing $\mathrm{N}$ concentration and it became more steeper under the deficiency of $\mathrm{N}$. Straightness of main root does not affected by the availability of $\mathrm{N}$ while the sources of nitrogen had significant effect and maximum straightness observed in organic $\mathrm{N}$ treated plant while minimum in ammonium treated. Lateral root number was increased with increasing nitrogen as nitrate and ammonia up to $100 \%$ as compared to organic N. Mean lateral root length was significantly affected by the sufficiency of nitrogen, while does not fluctuate with various forms of nitrogen. Sum of lateral root length was higher in nitrogen sufficiency. Lateral root density was significantly responding to availability and non-availability of nitrogen and significant reduction was observed in $0 \% \mathrm{~N}$ condition. Total root system size significantly influenced by sources and levels of nitrogen. Moreover, amongst root traits, total root system size was found least phenotypic plastic while lateral root density was ranked as highest phenotypic plastic trait due to nitrogen. The results indicate that combined nitrogen nutrition through nitrate and ammonia is most suitable for root system and seedling growth of rice as compared to the sole sources. The results of these study support the view that we need to breed varieties suited for organic agriculture and varieties such as IR-28, which is select and breed for high nitrogen input intensive agriculture, may not be efficient for organic nitrogen uptake and/or assimilation. 


\section{Introduction}

Nitrogen $(\mathrm{N})$ is a paramount element for crop productivity since it is a core component of many plant structures and for their metabolic processes. It is quantitatively the most important nutrient for plant development. Limited N availability has severe consequences for plant metabolism and growth resulting in lower biomass and yield of storage compounds (Epstein and Bloom, 2005). The 'green revolution' of the 1960s and 1970s helped agriculture to meet the food demands of a rapidly growing global population, through the development of dwarfed cereal cultivars, with high nitrogen responsiveness and better irrigation facilities. Past cereal production, including rice is mainly due to high application of $\mathrm{N}$ fertilizers together with the development of high yielding varieties. Approximately 85 to 90 Million Metric tons (MMt) of nitrogenous fertilizers are added to the soil worldwide annually up from 1.3 MMt in 1930 and 10.2 MMt in 1960 (Frink et al., 1999) and this is predicted to increase up to $240 \mathrm{MMt}$ by the year 2050 (Tilman et al., 2002). Nitrogen fertilization has been used for decades to increase crop yield with relatively low efficiency since a considerable fraction (up to two-third) of $\mathrm{N}$ input accumulates as runoffs (Frink et al., 1999), which dramatically affect the $\mathrm{N}$ cycle and associated processes (Vitousek et al., 1997 and galloway et al., 2008). The Nitrogen Use Efficiency (NUE) which may be defined as the yield obtained per unit of available $\mathrm{N}$ in the soil has declined sharply with increasing application of nitrogenous fertilizer. In most intensive agricultural production systems, over $50 \%$ and up to $75 \%$ of the $\mathrm{N}$ applied to the field is not used by the plant and is lost by leaching into the soil (Raun and Johnson, 1999) and nitrogen use efficiency is only 33\% (Abrol et al., 2007). The NUE of cereals, including rice, may be low because of modern breeding methods where selection trials are routinely carried out with sufficient to excess $\mathrm{N}$ provision often based on previous best practices and lines selected which respond to the applied $\mathrm{N}$ levels in the soil (Kamprath et al., 1982). $\mathrm{N}$ fertilization introduced $\mathrm{N}$ into the environment largely that resulted in significantly negative environment consequences (Brown, 2011). Nitrogen lost from agricultural system will entered to groundwater, lakes, estuaries and coastal water where the reactive nitrogen can participate and induces death of aquatic life as well as harms human and animal population as its negatively influence on drinking water availability. The production and extensive application of $\mathrm{N}$ fertilizer also contributed in major environmental problems due to soil leaching and greenhouse gas emission that play a large role in ozone depletion and global warming (Donner and Kucharik, 2008). In addition to these negative environmental effects, synthetic nitrogen fertilizer is typically the single highest input cost for many crops, since commercial fertilizer production (via Haber Bosch method) is energy intensive process.

Agriculture sector activities (mainly nitrogen fertilizer use) are the main contributor of global anthropogenic $\mathrm{N} 2 \mathrm{O}$ emission (ca. 58\%), soil deterioration and nutrients imbalance (Wuebbles, 2009). Nitrous oxide $(\mathrm{N} 2 \mathrm{O})$ is the third most abundant greenhouse gas (GHG) with only carbon dioxide $\left(\mathrm{CO}_{2}\right)$ and Methane $\left(\mathrm{CH}_{4}\right)$ being most prevalent (Montzka et al., 2011) and is a 300 times more potent GHG than $\mathrm{CO}_{2}$ (Johnson et al., 2007). India share $49 \% \mathrm{~N}_{2} \mathrm{O}$ emission in 2005 (Out of $267 \mathrm{Gg}$, where $\mathrm{Gg}=1000000 \mathrm{~kg}$ ) compared to $40 \%$ in 1985 (144 Gg) (Garg et al., 2012). In order to reduce eutrophication and the costly component of crop production, there is an immediate need to reduce $\mathrm{N}$ fertilizer inputs. The concept of sustainable agriculture leads to conservation of natural resources with the 
mitigation of climate change and increasing the productivity tend to move towards organic agriculture. It is based on minimizing the use of external inputs through use of on-farm resources efficiently compared to intensive agriculture and thus the use of synthetic fertilizers is avoided. Awareness of organic food for health conscious people steadily increases. There is an annual average growth rate of 20-25\% (Ramesh et al., 2005) increase in organic products demand. Worldwide over 130 countries produce certified organic products in commercial quantities (KortbechOlesen, 2000). An important issue to the acceptance of organic agriculture is found in the question of its low productivity. At present carrying capacity of organic agriculture only for 3-4 billion, well below the present world population ( $\approx 7$ billion) and that is projected up to 9 billion for 2050 (Connor, 2008). To meet food requirements of this future population FAO estimates that food production will have to increase by $70 \%$.

In organic agriculture, crop productivity is mainly limited due to nitrogen availability which is not easily controllable (Owen and Jones, 2001). The $\mathrm{N}$ availability dependent on mineralization of crop residues and farm yard manures applied on the farm. In early crop growth stages when demand is low, $\mathrm{N}$ is lost while in later stages the demand from the plant is often much greater than the supply from mineralization and matching $\mathrm{N}$ need and mineralization one of the major limiting factors in organic agriculture system.

One of the basic principles of soil fertility management in organic agriculture is that crop nutrition depends on biologically derived nutrient. Organic residues of low nutrient content (FYM, vermicompost, green manure etc.) added to the soil surface or incorporated into soil undergo decomposition by soil microbes. In addition to the readily available ammonium and nitrate ions, soil of organic agriculture can contain a wide range of organic nitrogen compounds such as peptides, proteins, free amino acids, amino sugars and nitrogen heterocyclic compounds (Mader et al., 2002; Jones et al., 2002). The organic nitrogen fraction typically comprises 0.1 to 0.5 $\%$ of total soil N (Barber, 1984).

NO3- and NH4+ ions are usually considered to be the main $\mathrm{N}$ forms in soil solution taken up by crop plants and to a lesser extent as proteins, peptides or amino acids. Some agricultural crop species have been shown to absorb organic $\mathrm{N}$ (Okamoto and Okada, 2004), for example, in rice, the $\mathrm{N}$ uptake rate increases with organic $\mathrm{N}$ supply rather than nitrate application (Yamagata and Ae, 1996). Studies on plant grown in solution culture or upon excised roots have also demonstrated that uptake of organic $\mathrm{N}$ can occur at a rate comparable to or in excess of $\mathrm{N}$ uptakes from inorganic $\mathrm{N}$ sources (Chapin et al., 1993; Raab et al., 1999). Under organic agriculture crop productivity mainly limited due to nitrogen availability (Mader et al., 2002) and additionally literature suggested that we need to breed differently for organic agriculture to increase their efficiency for nitrogen utilization (Sharma and Bardhan, 2017, Sharma et al., 2017).

Moreover acquisition of the various $\mathrm{N}$ forms is regulated not only by their chemical nature and spatial availability in the soil, but also by root system architecture, transport system in the plasma membrane of root cells and mechanism that regulate the activity of $\mathrm{N}$ transport systems and root growth, depending on plant requirements. From a fundamental point of view, the influence of nitrogen on root development is still poorly understood. Modifying root architecture is a strategy that aims at developing crops that capture nutrients more efficiently and are thus suitable for sustainable agriculture with fewer fertilizer inputs. The present investigation aims to study 
the responses of rice root system architecture to availability of different forms of nitrogen at seedling stage. However such experiment cannot be peprformed in the soils because of spatial and temporal variability of nitrogen in the soil, thus we choose to conduct our experiment in solid growing media under laboratory condition.

\section{Materials and Methods}

The study was conducted at the plant tissue culture laboratory, N.M. College of Agriculture, Navsari Agricultural University, Navsari, Gujarat, India $\left(20.9467^{\circ} \mathrm{N}, 72.9520^{\circ}\right.$

E) in September-October 2017. The rice seeds of IR-28 were provided by Regional Rice Research Station, Navsari Agricultural University, Vyara. In the study, polystyrene made optically clear and gamma irradiated pre-sterilized square petri dishes $(125 \times 125$ x20 $\mathrm{mm}^{3}$ ) having $139 \mathrm{~cm}^{2}$ of growing area were used.

\section{Growing condition}

The seeds were surface sterilized by immersing in 0.1 percent mercuric chloride for 10 minute. Then seeds were washed thoroughly with deionized water and before placing in nutrient media, the seeds were soaked for 24 hours in deionized water. Three rice seeds were placed in one petri dish (Fig. $1)$.

The cultured dishes were placed in vertical orientation in the racks of culture room of the laboratory. The culture room was maintained at $25^{\circ} \mathrm{C} \pm 1{ }^{\circ} \mathrm{C}, 60-70 \% \mathrm{RH}$ with providing 12 hours of photoperiod at about 2000 lux by cool white fluorescent tube light.

Total 126 petri dishes were used for the experiment. The experiment was laid down in complete randomized design with three repetitions.

\section{Growing media}

Yoshida's solution (Yoshida et al., 1976) was used as a growing media and each petri dish was poured with $100 \mathrm{ml}$ volume. The culture media was substituted with different sources of nitrogen on the basis of molar mass and the $\mathrm{pH}$ was maintained at 5.7 after mixing all the stock solution. Before pouring the media into the square dish the media was autoclaved at $121^{\circ} \mathrm{C}$ for $2 \mathrm{hrs} .8 \mathrm{~g} / \mathrm{L}$ Phytagel was added for the solidification of culture media.

\section{Nitrogen treatment application}

The experiment consist of fourteen treatments viz., three levels of nitrogen sources (nitrate, ammonia and organic nitrogen) and their combination with four levels of concentrations $(50,75,100$ and $125 \% \mathrm{~N})$ besides two controls (control - I, $100 \% \mathrm{~N}$ as in Yoshida solution and control- II, $0 \% \mathrm{~N}$, Yoshida solution).

According to the experimental treatments, all the individual stock solution prepared and calculations of different nitrogen sources and its level were calculated by using total nitrogen concentration in the standard Yoshida solution. In standard Yoshida solution, nitrogen was supplied by $\mathrm{NH}_{4} \mathrm{NO}_{3}(91.4 \mathrm{~g} / \mathrm{lit})$. As per our experimental treatments, the nitrogen was substituted by using different sources and desired concentration level were maintained on the basis of molecular mass (Table 1 to Table 3). $\mathrm{NH}_{4} \mathrm{NO}_{3}, \mathrm{KNO}_{3}$, $\left(\mathrm{NH}_{4}\right)_{2} \mathrm{SO}_{4}$ and amino acid mixture (Glycine, L- Glutamic acid and L-Aspartic acid) were used for substitution of nitrogen from the Yoshida solution.

\section{Root system analysis}

Total 126 images of root system were captured by digital camera (Sony Cybershot) on 21 day after emergence (3 images per 
treatment per repetition). These images were processed as per the guidelines of the EzRhizo software (Armengaud et al., 2009) and the data obtained was converted to mean value for each parameter (Fig. 2).

Table.1 Substitution of nitrate as sole N source (g/lit)

\begin{tabular}{|l|l|l|l|l|}
\hline \multicolumn{1}{|c|}{ Chemicals } & \multicolumn{1}{|c|}{$\mathbf{5 0 \%}$} & \multicolumn{1}{c|}{$\mathbf{7 5 \%}$} & \multicolumn{1}{c|}{$\mathbf{1 0 0 \%}$} & \multicolumn{1}{c|}{$\mathbf{1 2 5 \%}$} \\
\hline $\mathbf{K N O}_{\mathbf{3}}$ & $82.85 \mathrm{gm}$ & $82.85 \mathrm{gm}$ & $82.85 \mathrm{gm}$ & $82.85 \mathrm{gm}$ \\
\hline $\mathbf{C a N O}_{\mathbf{3}}$ & $38.10 \mathrm{gm}$ & $105.45 \mathrm{gm}$ & $172.89 \mathrm{gm}$ & $236.44 \mathrm{gm}$ \\
\hline $\mathbf{C a C l}_{\mathbf{2}}$ & $70.69 \mathrm{gm}$ & $39.04 \mathrm{gm}$ & $7.33 \mathrm{gm}$ & -- \\
\hline $\mathbf{H C l}$ & $9.88 \mathrm{ml}$ & $27.36 \mathrm{ml}$ & $44.86 \mathrm{ml}$ & $48.91 \mathrm{ml}$ \\
\hline
\end{tabular}

Table.2 Substitution of $\mathrm{NH}_{4}{ }^{+}$as sole $\mathrm{N}$ source (g/lit)

\begin{tabular}{|l|l|l|l|l|}
\hline \multicolumn{1}{|c|}{ Chemicals } & \multicolumn{1}{|c|}{$\mathbf{5 0 \%}$} & \multicolumn{1}{|c|}{$\mathbf{7 5 \%}$} & \multicolumn{1}{c|}{$\mathbf{1 0 0 \%}$} & \multicolumn{1}{c|}{$\mathbf{1 2 5 \%}$} \\
\hline $\mathbf{N H}_{\mathbf{4}} \mathbf{H}_{\mathbf{2}} \mathbf{P O}_{\mathbf{4}}$ & $29.71 \mathrm{gm}$ & $29.71 \mathrm{gm}$ & $29.71 \mathrm{gm}$ & $29.71 \mathrm{gm}$ \\
\hline $\mathbf{( N H}_{\mathbf{4}} \mathbf{S}_{\mathbf{2}} \mathbf{S O}_{\mathbf{4}}$ & $58.36 \mathrm{gm}$ & $96.02 \mathrm{gm}$ & $133.74 \mathrm{gm}$ & $133.74 \mathrm{gm}$ \\
\hline $\mathbf{N H}_{\mathbf{4}} \mathbf{C l}$ & -- & -- & -- & $30.55 \mathrm{gm}$ \\
\hline
\end{tabular}

Table.3 Substitution of organic nitrogen as sole N source (g/lit)

\begin{tabular}{|l|r|r|r|r|}
\hline \multicolumn{1}{|c|}{ Amino acid } & $\mathbf{5 0 \%}$ & $\mathbf{7 5 \%}$ & $\mathbf{1 0 0} \%$ & $\mathbf{1 2 5} \%$ \\
\hline Glycine & $28.56 \mathrm{gm}$ & $38.53 \mathrm{gm}$ & $57.13 \mathrm{gm}$ & $71.44 \mathrm{gm}$ \\
\hline L- glutamic acid & $55.98 \mathrm{gm}$ & $83.93 \mathrm{gm}$ & $111.97 \mathrm{gm}$ & $140.01 \mathrm{gm}$ \\
\hline L- Aspartic acid & $50.65 \mathrm{gm}$ & $75.92 \mathrm{gm}$ & $101.29 \mathrm{gm}$ & $126.67 \mathrm{gm}$ \\
\hline
\end{tabular}

\section{Other observations}

Nitrogen content in shoot and root samples were observed by weight digestion method along with shoot and root dry weight per seedling at 21 days after emergence.

\section{Statistical analysis}

All mean values were subjected for statistical analysis for control vs rest design of factorial concept (Panse and Sukahtme, 1978) of the experiment and analysis was performed by department of agricultural statistics, N. M. College of Agriculture, NAU, Navsari. The significance of difference was tested by 'F" test at five per cent level. The critical differences was calculated whenever the difference among treatment found significant.

\section{Results and Discussion}

Needless to say, thus the ability of plants to quickly and efficiently modulating its root architecture may determine its comparative success and productivity in nitrogen limiting environments. Under such condition plants activate foraging responses that induced morphological changes and modulated root system architecture, besides physiological and metabolic changes. Both nutritional status of the plant and the external nutrient availability can induce changes in overall root morphology (Giehl et al., 2014). Root system architecture (RSA) defined as the spatial configuration of root system is the fundamental aspect in plant productivity 
(Lynch, 1995). The ability of a plant to modify the RSA based on nutritional status of the surrounding, so called plasticity is currently the most accepted target trait for nitrogen use efficiency.

The results of primary root length (Fig. 3A) indicated significant increase in root length due to nitrogen unavailability. The primary root length of rice seedling was found significantly influenced by nitrogenous forms and their different levels. Results indicated that in control-I (100\% N, Yoshida solution) significantly minimum root length was observed while control-II $(0 \% \mathrm{~N}$, Yoshida solution) recorded significantly maximum root length. Deficiency in $\mathrm{N}$ results in a shift in dry matter in favor of root growth. (Ericsson 1995) and thus higher root growth was observed in control- II. Similarly in nitrogen deficiency, increase in primary root growth was observed by other workers (Linkohr et al., 2002, Lopez-Bucio et al., 2003). Various forms of nitrogen also influenced primary root length and minimum root length was observed with nitrate form which was statistically at par with ammonical form and control- I. Root proliferation and overall plant growth are usually greater with mixture of $\mathrm{NH} 4+$ and NO3- than with either form alone (Wang and Below 1992, Saravitz et al., 1994, Schortemeyer and Feil, 1996) as indicated in $100 \% \mathrm{~N}$ Yoshida solution (control-I). Rice is known as efficient for NH4+ (Wang et al., 1993) as well as exceptionally efficient in absorbing NO3- also (Duan et al., 2006). Maximum primary root length was recorded for organic nitrogen nutrition, which also exhibited maximum carbon allocation and up to $33 \%$ of shoot biomass reduction was recorded as compared to control- I (100\% N Yoshida solution) (Fig. 5). This suggesting nitrogen starvation in IR-28 seedlings under organic nitrogenous nutrition. Root length under various levels also supported the above discussed fact that nitrogen deficiency increases the root length and maximum and minimum root length were recorded with 50 $\%$ and $125 \%$ levels of nitrogen, respectively. However, at $125 \%$ of nitrogen, decreased in root length was observed with nitrate and ammonical form but not in organic form. Reduction in ammonical nitrogen may be attributed to its toxicity. Although rice is known as NH4+ tolerant species (Wang et al., 1993) can be negatively affected by elevated NH4+ levels (Balkos et al., 2010). Excessive $\mathrm{NH} 4+$ is also known to inhibit the growth of most crop species (Roosta and Schjoerring 2008). Infact stunted root growth is considered as principal symptom of ion toxicity (Gerendas et al., 1997; Britto and Kronzucker, 2002, Balkos et al., 2010). However, in the present study, at $125 \%$ level of nitrogen, nitrate nitrogen found more toxic than ammonical nitrogen.

In several crop species, genetic variation in axial root growth angle is associated with rooting depth as in common bean and maize shallow growth angles enhances top soil foraging and acquisition of top soil resources such as phosphorus (Zhu et al., 2005; Lynch 2011). In common bean, wheat, sorghum and rice, steep growth angles enhances subsoil foraging and water acquisition under terminal draught (Ho et al., 2005; Manschadi et al., 2008; Uga et al., 2011; Mace et al., 2012). In the present study, main root angle $\left({ }^{\mathrm{O}}\right.$ ) (Fig. $4 \mathrm{G})$ tend to steeper in nitrogen deficit treatments and maximum angle was recorded for control-I while significantly narrow angle was recorded in control-II. Nitrate and ammonical nitrogen had similar effect on root angle while organic nitrogen treatment significantly decreases the main root angle. Previous reports suggesting no influence of nitrogen on root angle (Forde and Lorenzo, 2001), However, Trachasel et al., (2013) reported decreased brace and crown root angle under low $\mathrm{N}$ condition in maize. In the present study, straightness of main root (Fig. 4H) was 
not significantly influence by nitrogen availability, though form of nitrogen significantly influencing straightness of main root and in organic form, it was maximum as compared to ammonium and nitrate. This might be due to the fact that in organic nitrogenous treatment, seedling experiencing nitrogen limitation as supported by all other traits and thus root angle decrease more in organic and increases straightness as compared to ammonia and nitrate.

Lateral root number (Fig. 3B) of rice significantly varied in different forms of nitrogen nutrition and significantly maximum lateral root numbers were observed under nitrate nutrition while lowest number recorded with organic form of nitrogen. It has been shown that, nitrate stimulates lateral root growth by regulating auxin activity and it increases auxin accumulation in primary root tips (Vidal et al., 2010). There are strong connections reported between auxin and nitrate signaling, which could cooperatively regulate lateral root development (Zhang et al., 1999; Gutierrez et al., 2007, Tian et al., 2008; Krouk et al., 2010; Mounier et al., 2014).

As in the present study, along with lateral root number, sum of total lateral root length (Fig. 3D) was also recorded maximum in nitrate nitrogen. However, lateral root number, mean lateral root length and sum of lateral root length were significantly higher recorded in control-I (100\% N Yoshida solution), where both nitrate and ammonical nitrogen were available. It seems to have complementary effects of availability of nitrate and ammonia on lateral root development because ammonium stimulates branching whereasnitrate stimulates lateral root elongation (Remans et al., 2006; Lima et al., 2010). Moreover, nitrogen deficiency shown to inhibit lateral root emergence as Krouk et al., (2010) suggested that severe nitrogen limitation caused less auxin accumulation in lateral root primordia and thus lateral root emergence is hampered. In present study, significantly lower lateral root development was observed in 50\% nitrogen supply. Though, it seems that in present study, rice seedlings were not experiencing severe nitrogen deficiency as reported elsewhere that in severe deficiency, total lateral root length was decreased and completely absent of lateral root formation (Krouk et al., 2010, Gruber et al., 2013).

Moreover, lateral root length and sum of lateral root length was decreased at higher dose of nitrogen nutrition (Fig. $3 \mathrm{C}$ and $3 \mathrm{D}$ ). It may be due to besides auxin signaling, high nitrogen may affect auxin concentration also. For instance, when external nitrate concentration was greater, the elongation of lateral root in maize was inhibited, which was due to reduction of auxin translocation from shoot to root in phloem (Tian et al., 2008). Therefore, a reduced auxin level in root resulted in the inhibition of lateral root growth. Moreover higher concentration of nitrate also inhibited lateral root growth through ABA signaling (Signora et al., 2001, Vidal et al., 2010). Lateral root density of IR 28 seedling (Fig. 4E) was found more in nitrate as compared to ammonical and organic nitrogen nutrition.

However, at higher concentration of supply, in all forms of nitrogen, lateral root density was decreased. It may be attributed to root plasticity where plant roots adopt an economic saving model with lateral root inhibition to reserve energy and carbon skeleton for other usage.

Similar to our results, where at $100 \%$ of nitrogen nutrition, greater lateral root density, lateral root number and sum of lateral root length observed, in barley also nutrient rich 'patch' elicit in lateral root initiation and elongation (Drew, 1975). 
Table.4 Shoot dry weight (mg/plant) of rice seedlings as influenced by various nitrogenous treatments

\begin{tabular}{|c|c|c|c|c|c|c|c|}
\hline \multirow[t]{2}{*}{ Level of nitrogen } & \multicolumn{3}{|c|}{ Forms of nitrogen } & \multirow[t]{2}{*}{ Mean } & \multicolumn{3}{|c|}{ ANOVA } \\
\hline & $\mathrm{NO}_{3}^{-}$ & $\mathrm{NH}_{4}^{+}$ & Organic & & & S.Em \pm & CD at $5 \%$ \\
\hline $50 \%$ & 20.2 & 20.5 & 18.0 & 19.6 & Treatment & 0.55 & 1.60 \\
\hline $75 \%$ & 24.1 & 22.5 & 18.0 & 21.5 & Nitrogen forms $(\mathbf{N})$ & 0.28 & 0.80 \\
\hline $100 \%$ & 27.5 & 23.6 & 18.8 & 23.3 & Level of nitrogen $(\mathrm{L})$ & 0.32 & 0.93 \\
\hline $125 \%$ & 18.9 & 19.3 & 17.6 & 18.6 & $\mathbf{N} \times \mathbf{L}$ & 0.55 & 1.60 \\
\hline Mean & 22.6 & 21.5 & 18.1 & 20.73 & $0 \%$ N vs Rest & 0.41 & 1.18 \\
\hline $\begin{array}{l}\text { Control-I (100\% N Full } \\
\text { Yoshida solution) mean }\end{array}$ & \multicolumn{4}{|c|}{28.1} & $\begin{array}{l}100 \% \text { vs } 0 \% \\
\text { Nitrogen }\end{array}$ & 0.55 & 1.60 \\
\hline $\begin{array}{c}\text { Control-II (0\% N } \\
\text { Yoshida solution -N) } \\
\text { mean }\end{array}$ & \multicolumn{4}{|c|}{17.5} & CV \% & \multicolumn{2}{|c|}{4.55} \\
\hline
\end{tabular}

Table.5 Root dry weight (mg/plant) of rice seedlings as influenced by various nitrogenous treatments

\begin{tabular}{|c|c|c|c|c|c|c|c|}
\hline Level of nitrogen & \multicolumn{3}{|c|}{ Forms of nitrogen } & Mean & \multicolumn{3}{|c|}{ ANOVA } \\
\hline $50 \%$ & 14.2 & 14.0 & 13.3 & 13.8 & Treatment & 0.45 & 1.30 \\
\hline $100 \%$ & 17.5 & 18.2 & 14.0 & 16.6 & Level of nitrogen $(\mathrm{L})$ & 0.26 & 0.75 \\
\hline $125 \%$ & 13.2 & 13.5 & 13.7 & 13.5 & $\mathbf{N} \times \mathbf{L}$ & 0.45 & 1.30 \\
\hline Mean & 14.9 & 15.3 & 13.7 & 14.6 & $0 \%$ N vs Rest & 0.33 & 0.96 \\
\hline $\begin{array}{l}\text { Control-II (0\% N } \\
\text { Yoshida solution - } \\
\text { N) mean }\end{array}$ & \multicolumn{4}{|c|}{13.5} & $\mathrm{CV} \%$ & \multicolumn{2}{|c|}{5.24} \\
\hline
\end{tabular}


Table.6 Nitrogen content in shoot $\left(\mathrm{mg} \cdot \mathrm{g}^{-1}\right)$ of rice seedlings as influenced by various nitrogenous treatments

\begin{tabular}{|c|c|c|c|c|c|c|c|}
\hline \multirow[t]{2}{*}{ Level of nitrogen } & \multicolumn{3}{|c|}{ Forms of nitrogen } & \multirow[t]{2}{*}{ Mean } & \multicolumn{3}{|c|}{ ANOVA } \\
\hline & $\mathrm{NO}_{3}^{-}$ & $\mathrm{NH}_{4}^{+}$ & Organic & & & S.Em \pm & CD at $5 \%$ \\
\hline $50 \%$ & 1.92 & 1.49 & 1.29 & 1.57 & Treatment & 0.03 & 0.07 \\
\hline $75 \%$ & 2.15 & 1.63 & 1.25 & 1.68 & Nitrogen forms $(\mathrm{N})$ & 0.01 & 0.04 \\
\hline $100 \%$ & 2.94 & 2.21 & 1.15 & 2.10 & Level of nitrogen $(\mathrm{L})$ & 0.01 & 0.04 \\
\hline $125 \%$ & 1.33 & 1.46 & 1.09 & 1.29 & $\mathbf{N} \times \mathbf{L}$ & 0.03 & 0.07 \\
\hline Mean & 2.09 & 1.70 & 1.20 & 1.66 & $0 \%$ N vs Rest & 0.02 & 0.05 \\
\hline $\begin{array}{l}\text { Control-I (100\% N Full } \\
\text { Yoshida solution) mean }\end{array}$ & \multicolumn{4}{|c|}{3.06} & $\begin{array}{l}100 \% \text { vs } 0 \% \\
\text { Nitrogen }\end{array}$ & 0.03 & 0.07 \\
\hline $\begin{array}{c}\text { Control-II ( }(0 \% \text { N Yoshida } \\
\text { solution }-\mathrm{N}) \text { mean }\end{array}$ & \multicolumn{4}{|c|}{1.07} & CV \% & \multicolumn{2}{|c|}{2.57} \\
\hline
\end{tabular}

Table.7 Nitrogen content in root $\left(\mathrm{mg} \mathrm{g}^{-1}\right)$ of rice seedlings as influenced by various nitrogenous treatments

\begin{tabular}{|c|c|c|c|c|c|c|c|}
\hline \multirow[t]{2}{*}{ Level of nitrogen } & \multicolumn{3}{|c|}{ Forms of nitrogen } & \multirow[t]{2}{*}{ Mean } & \multicolumn{3}{|c|}{ ANOVA } \\
\hline & $\mathrm{NO}_{3}{ }^{-}$ & $\mathrm{NH}_{4}^{+}$ & Organic & & & S.Em \pm & CD at $5 \%$ \\
\hline $50 \%$ & 0.76 & 0.99 & 0.70 & 0.81 & Treatment & 0.02 & 0.06 \\
\hline $100 \%$ & 1.36 & 1.14 & 1.01 & 1.17 & Level of nitrogen $(\mathrm{L})$ & 0.01 & 0.04 \\
\hline $125 \%$ & 0.81 & 0.75 & 0.96 & 0.84 & $\mathbf{N} \times \mathbf{L}$ & 0.02 & 0.06 \\
\hline Mean & 0.96 & 0.98 & 0.85 & 0.93 & $0 \%$ N vs Rest & 0.02 & 0.05 \\
\hline $\begin{array}{l}\text { Control-II (0\% N } \\
\text { Yoshida solution - } \\
\text { N) mean }\end{array}$ & \multicolumn{4}{|c|}{0.52} & $\mathrm{CV} \%$ & \multicolumn{2}{|c|}{3.91} \\
\hline
\end{tabular}


Figure.1 Root System Architecture of IR-28 at 21 days after emergence, under varied nitrogen sources and availabilities
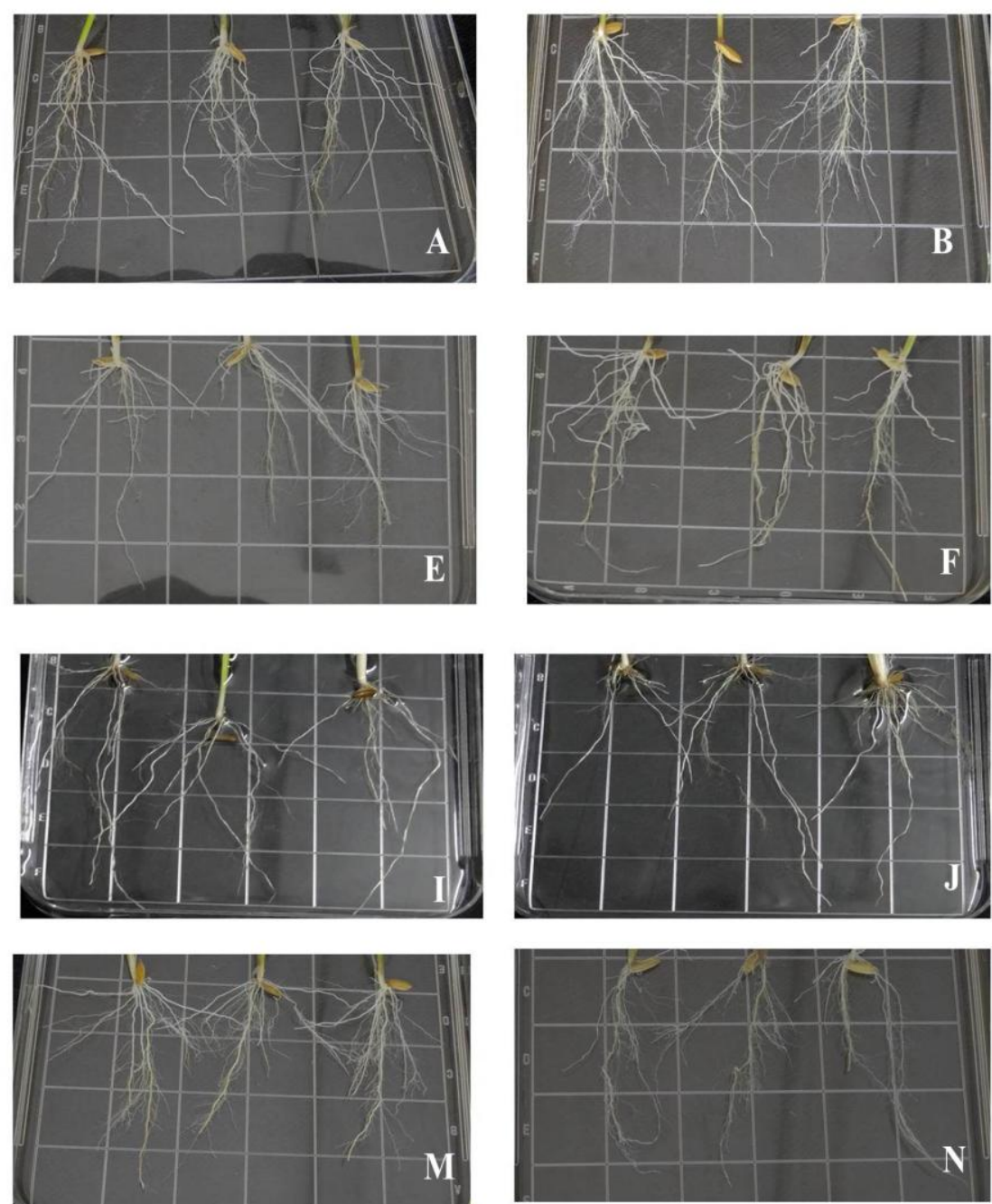
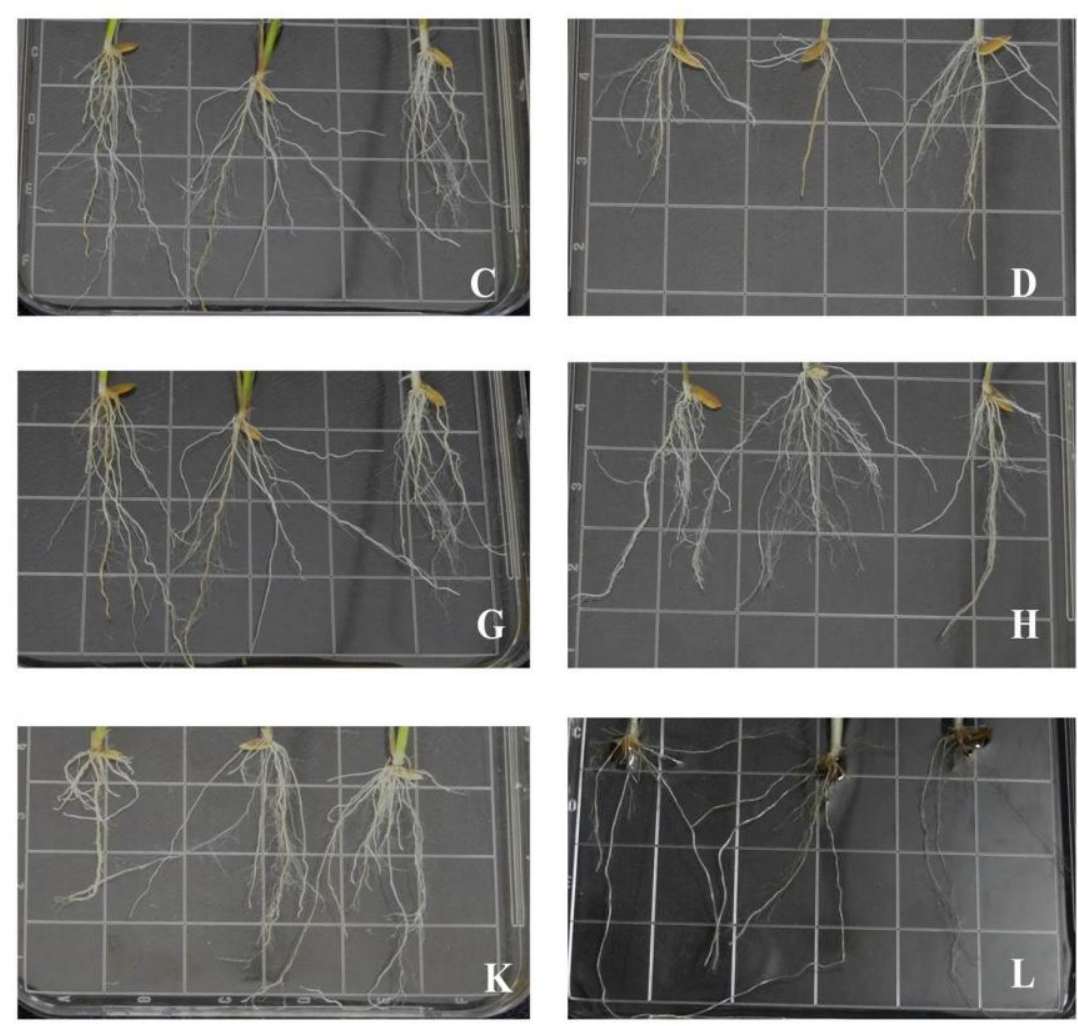

A- Nitrate 50\%, B- Nitrate $75 \%$, C- Nitrate $100 \%$, D- Nitrate 125\%, E- Ammonia 50\%, F- Ammonia 75\%, G- Ammonia 100\%, H- Ammonia 125\%, I- Organic N 50\%, J- Organic N 75\%, KOrganic N 100\%, L- Organic N 125\%, M- Yoshida Solution $(100 \%$ N), N- Yoshida Solution (0\% N) 
Table.8 Plasticity of root traits of rice seedlings as influenced by various nitrogenous treatments

\begin{tabular}{|l|c|}
\hline \multicolumn{1}{|c|}{ Root traits } & Plasticity value \\
\hline Primary root length & $0.030^{\mathrm{NS}}$ \\
\hline Main root angle & $-0.053^{*}$ \\
\hline Straightness of main root & $-0.016^{\mathrm{NS}}$ \\
\hline Lateral root number & $-0.314^{* *}$ \\
\hline Mean lateral length & $-0.300^{\mathrm{NS}}$ \\
\hline Sum of lateral length & $-0.298^{* *}$ \\
\hline Lateral root density & $-0.328^{* *}$ \\
\hline Total root system size & $-0.278^{*}$ \\
\hline
\end{tabular}

Figure.2 Example of root system skeletonized image output of Ez-Rhizo for all nitrogenous treatments

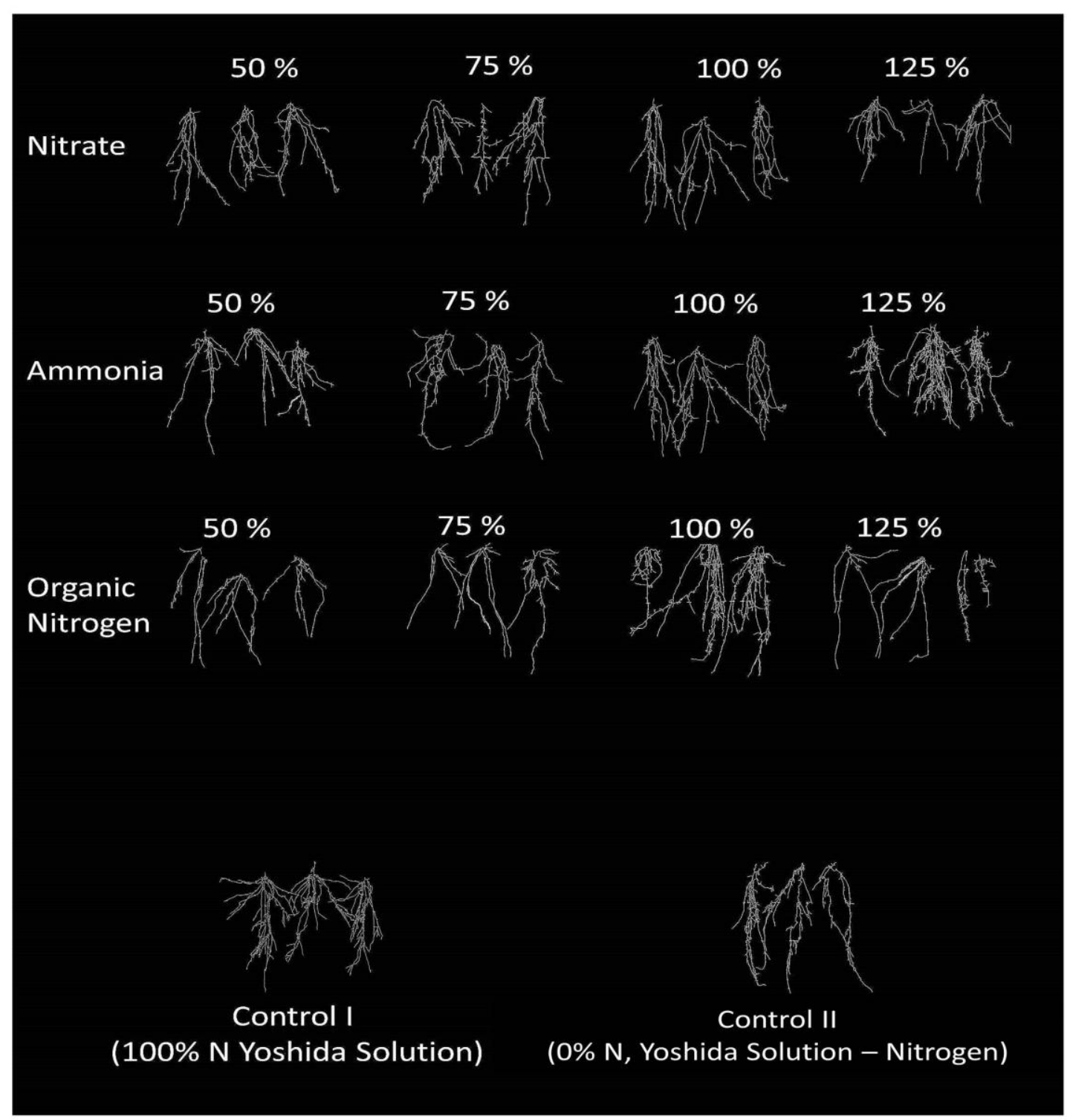


Figure.3 Primary root length (A), lateral root number (B), mean lateral root length (C) and sum of lateral root length (D) of rice (IR-28) seedling as influenced by various nitrogenous forms and availabilities. Any two means followed by a common alphabet are not significantly differed from each other by LSD at $\mathrm{p}=0.05$

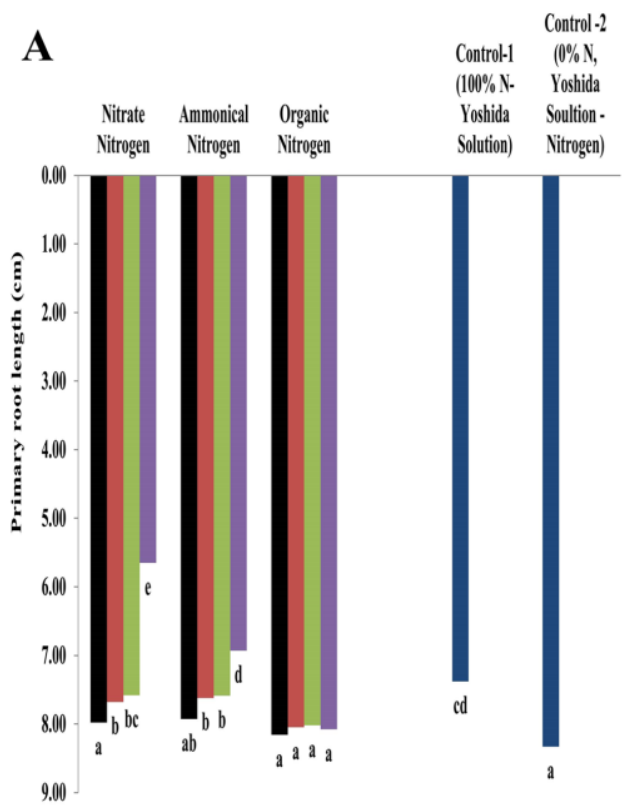

$\mathrm{LSD}_{\mathrm{N} .15}=0.54, \mathrm{~S} . \mathrm{Em}= \pm 0.19$

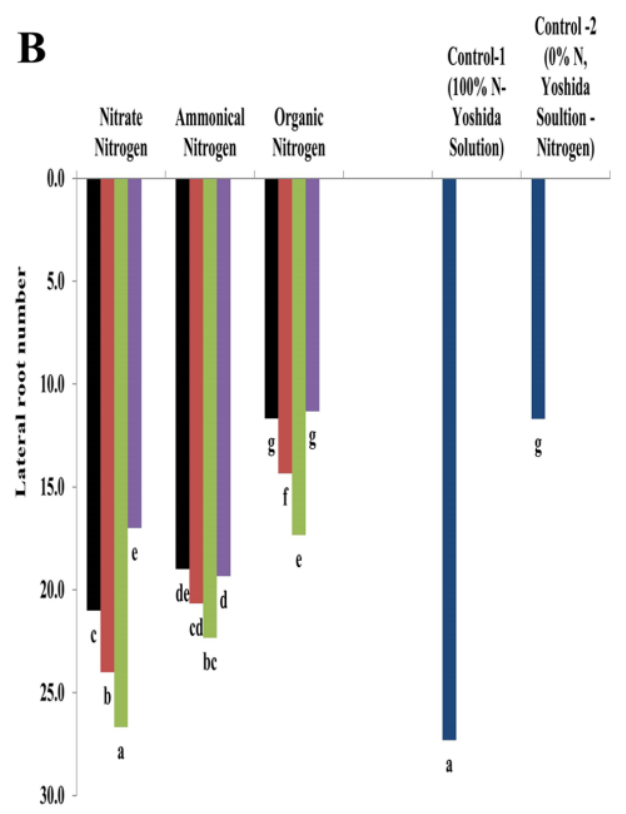

$L \mathrm{LS}_{0.15}=2.34, \mathrm{~S} . \mathrm{Em}= \pm 0.81$
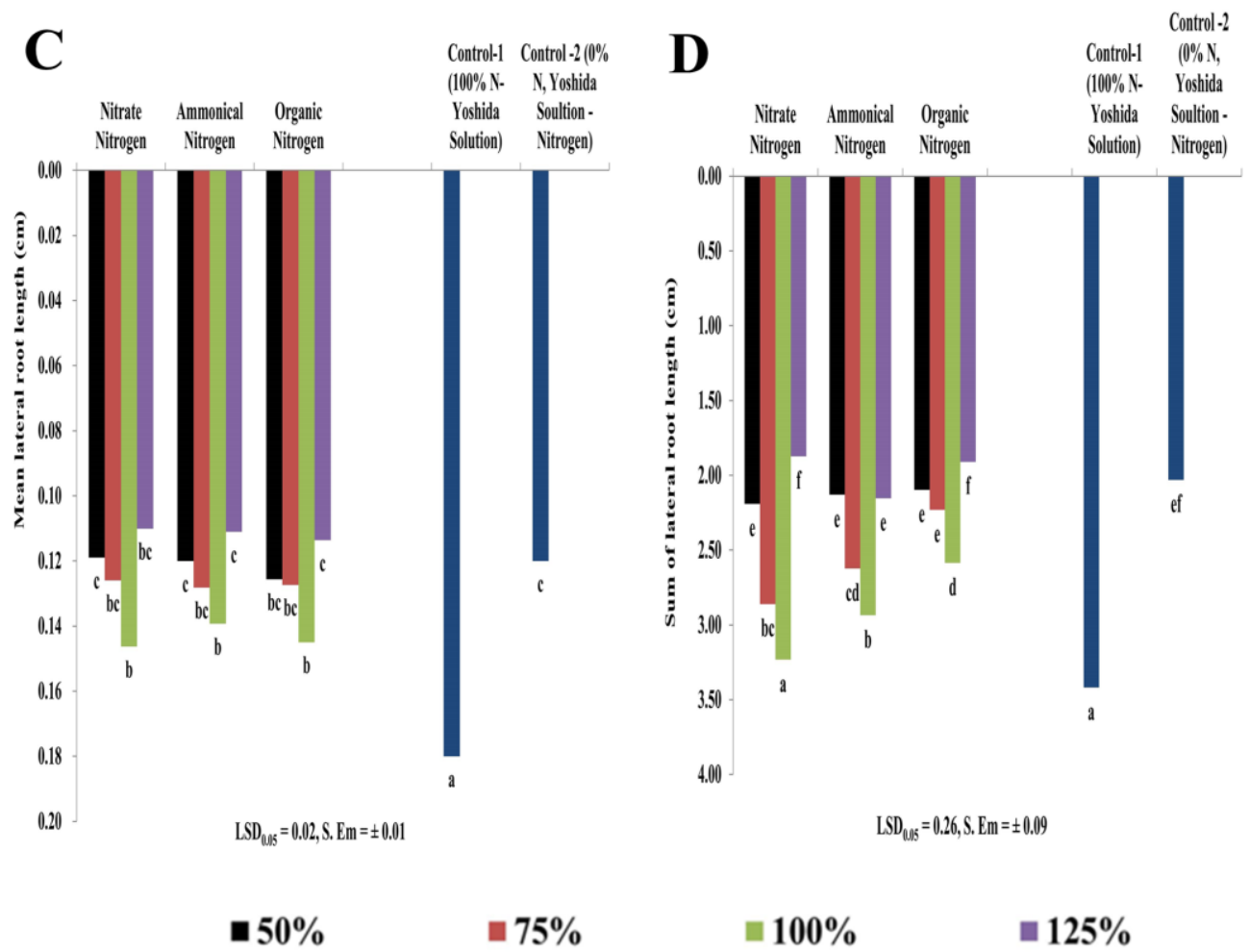
Figure.4 Lateral root density (E), total root system size (F), main root angle (G) and straightness of main root $(\mathrm{H})$ of rice (IR-28) seedling at 21 days after emergence, as influenced by various nitrogenous forms and availabilities. Any two means followed by a common alphabet are not significantly differed from each other by LSD at $\mathrm{p}=0.05$

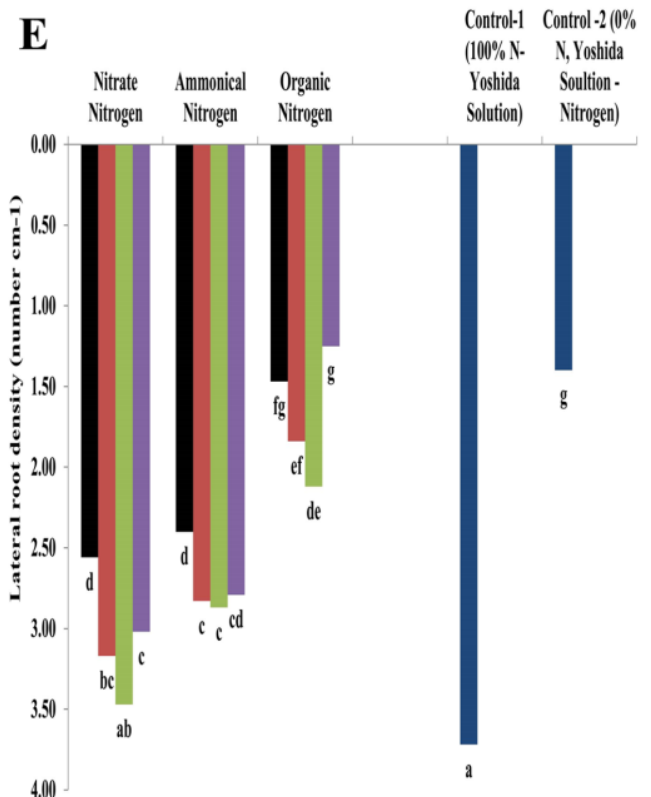

$L S D_{0.15}=0.39, S . E m= \pm 0.13$

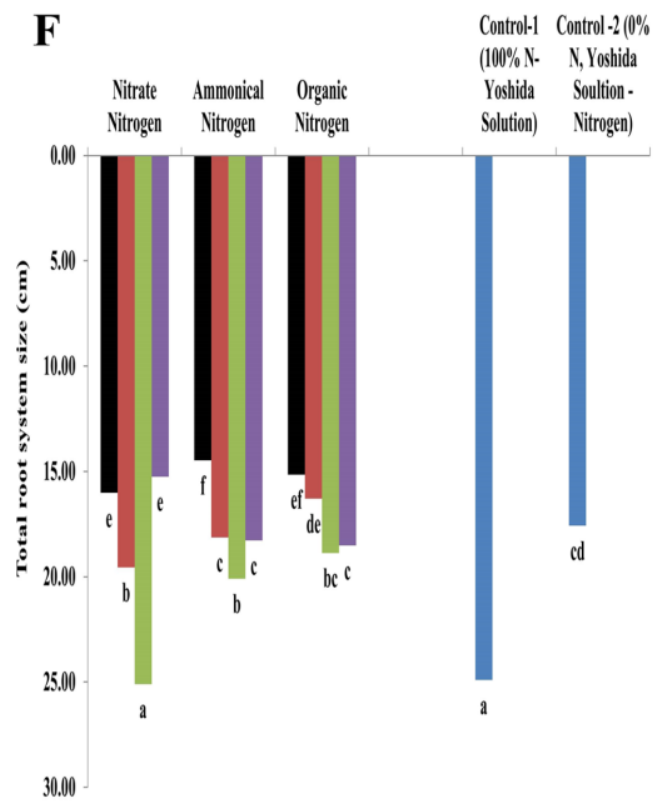

$L S D_{1,15}=1.41, S . E m= \pm 0.49$
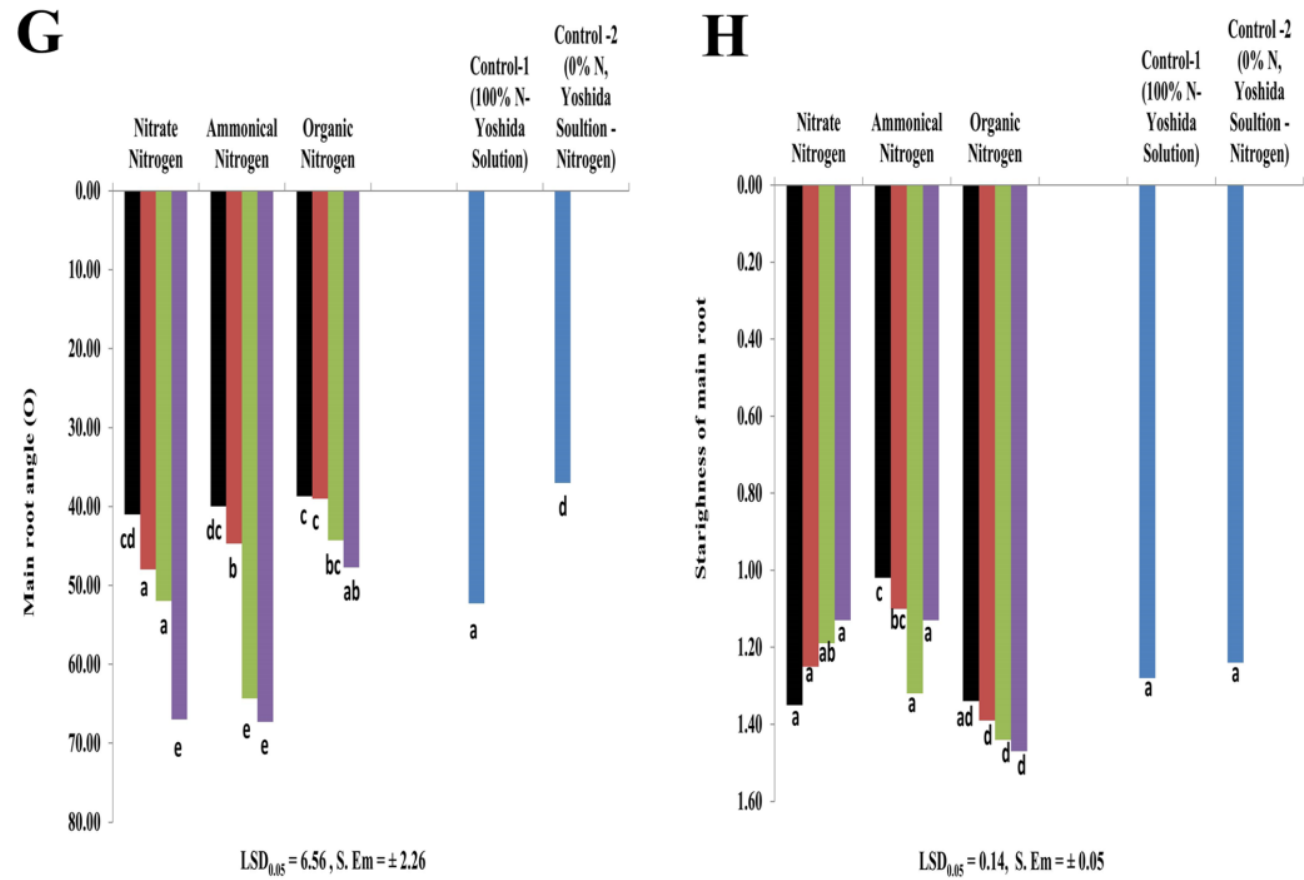
$\mathbf{- 5 0 \%}$
$\square 75 \%$

$\because 100 \%$

$125 \%$ 
Figure.5 Percent reduction into total root system size, shoot biomass and root biomass of IR- 28 under $100 \%$ of nitrate, ammonical and organic nitrogen nutrition over control-I(100\% N Yoshida solution)
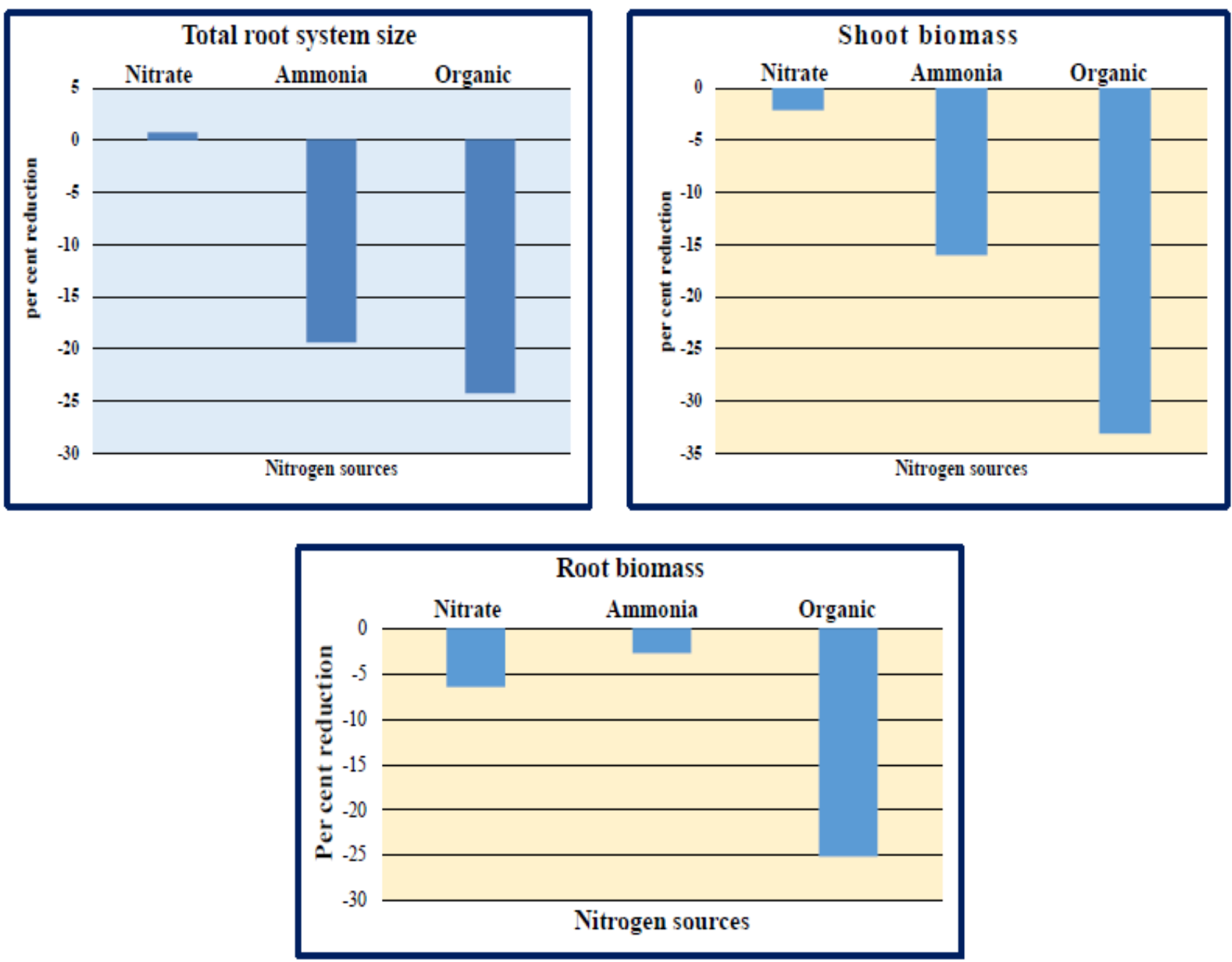

High supply of $\mathrm{N}$ as with $125 \%$ level of nitrogen treatment, suppression of lateral root growth was also reported in many species. In A. thaliana, $\mathrm{NO}_{3}$ concentration over $10 \mathrm{mM}$ inhibits lateral root development by preventing meristem activation in newly emerged primordia (Nacry et al., 2013). In the present study, at higher $\mathrm{N}$ level (125\%), 32\% reduction was reported in sum of lateral root length while $28 \%$ reduction recorded in lateral root number over $100 \%$ nitrogen nutrition (Fig. 3B and 3D). It may be due to arrestation of lateral root growth after emergence from the primary root (Zhang et al., 1999). In the present study, IR-28 seedling shoots and root dry weight (Table 4 and 5) significantly influenced by nitrogenous form and their levels. Significantly maximum shoot and root dry weight were recorded for control-I (100\% N Yoshida solution) where both $\mathrm{NH}_{4}{ }^{+}$and $\mathrm{NO}_{3}$ - forms were available. In sole treatment, nitrate form significantly increased shoot dry weight over ammonical and organic nitrogen nutrition while in root biomass effect of nitrate and ammonia were similar, though recorded higher root dry weight as compared to organic nitrogen. 
Similar result trend was also reported for shoot and root nitrogen content (Table 6 and 7) with increasing levels of nitrogen, shoot and root dry weight along with $\mathrm{N}$ content increased up to $100 \%$ level. Nitrate form found to be superior over ammonical form for shoot biomass and it may be attributed to the fact that NH4+ assimilation demands more assimilates and excretion as ammonical ion, owing to its toxicity, require more assimilates, results in lower shoot biomass (Kronzucker et al., 2001).

In maize also, nitrate form found superior over ammonical nitrogen nutrition for biomass (Bennett et al., 1964). In our study, mixtures of amino acid showed nitrogen deficiency phenotype for most of the studied root traits and also reflected in shoot and root dry weight. However, shoot and root $\mathrm{N}$ content in organic form was significantly higher than control-II $(0 \% \mathrm{~N}$, Yoshida solution), though remain lower than ammonical and nitrate nitrogen. It indicated slower absorption of amino acids. However, Gioseffi et al., (2012) reported in wheat that uptake rate of $\mathrm{NO}_{3}$ - and $\mathrm{NH}_{4}+$ did not differ from each other and were generally twice as high as uptake rate of organic N. Moreover, amino acids also reported to inhibit nitrate reductase activity in corn roots and thus $\mathrm{N}$ assimilation process may also hindrance (Oaks et al., 1977).

\section{Root phenotypic plasticity}

Root architectural plasticity is an important feature to confer adaptability across variable environments. In this study, root architectural plasticity of IR- 28 seedling was evaluated under various nitrogenous forms and their level over $100 \%$ nitrogen environment of Yoshida solution (Table-8) (Sandhu et al., 2016). It aims to identify particular root trait which are highly plastic in nature and conferred adoptability of IR-28 seedling in various nitrogen environment. Root trait phenotypic plasticity was calculated as the relative change in individual trait under different regimes of nitrogenous form as compared to control-I $(100 \% \mathrm{~N}$, Yoshida solution). Amongst root traits, all traits showed significant plasticity (at $\mathrm{P}=0.05$ level) over control-I condition, except primary root length and straightness of main root. However, negative plasticity indicate that these traits were decreased under different level of nitrogen nutrition over control-I, which further signified synergistic effect of ammonical and nitrate nutrition over sole sources viz., ammonia, nitrate and organic $\mathrm{N}$ (amino acid mixture). Maximum root phenotypic plasticity was recorded for lateral root density while significant lowest root phenotypic plasticity was recorded for total root system size.

In this study, it is concluded that different forms of nitrogen viz. ammonia, nitrate and organic (mixture of amino acids), have remarkable and contrasting effects on root system architecture in rice. To the best of our knowledge, it is first of its kind report where organic nitrogen nutrition compared with inorganic nitrogenous sources on root system architecture. The results indicated that combined nitrogen nutrition through nitrate and ammonia is most suitable for root system and seedling growth of IR-28 as compared to sole source. Organic nitrogen nutrition was found least suitable, even at higher concentration where ammonia and nitrate showed inhibitory/toxic effects, root system of IR-28 in organic nitrogen treatment showed phenotype of nitrogen starvation. The results of these study support the view that we need to breed varieties suited for organic agriculture and varieties such as IR-28, which is select and breed for high nitrogen input intensive agriculture, may not be suitable for organic agriculture. However, to confirm responses of root system architectural traits to 
organic nitrogen, we suggest to replicate the study with wild and/or land races of rice, which may have high uptake and assimilation efficiency for organic nitrogen.

\section{References}

Abrol, Y. P., Raghuram, N., and Sachdev, M. S. (2007). Agricultural nitrogen use and its environmental implications. IK International, pp: 552.

Armengaud, P., Zambaux, K., Hills, A., Sulpice, R., Pattison, R.J., Blatt, M.R. and Amtmann, A. (2009). EZ-Rhizo: integrated software for fast and accurate measurement of root system architecture. Plant J., 57: 945-956.

Balkos, K. D., Britto, D. T. and Kronzucker, H. J. (2010). Optimization of ammonium acquisition and metabolism by potassium in rice (Oryza sativa L. cv. IR-72). Plant Cell Environ., 33: 23-34.

Barber, S. A. (1984). Soil nutrient bioavailability: a mechanistic approach. John Wiley and Sons, New York, pp: 398.

Bennett, W. F., Pesek, J., and Hanway, J. J. (1964). Effect of nitrate and ammonium on growth of corn in nutrient solution sand culture. Agronomy Journal, pp: 342-345.

Britto, D. T. and Kronzucker, H. J. (2002). NH4+ toxicity in higher plants: a critical review. J. Plant Physiol., 159: 567-584.

Brown LR (2011) World on the edge. How to prevent environmental and economic collapse. New York, WW Norton \& Company, p: 240.

Chapin, F. S., Moilanen, L. and Kielland, K. (1993). Preferential use of organic nitrogen for growth by nonmycorrhizal arctic sedge. Nature, 361: 150-153.

Connor DJ (2008) Organic agriculture cannot feed the world. Field Crop research 106: 187-190.

Donner, S. D. and Kucharik, C. J. (2008). Corn-based ethanol production compromises goal of reducing nitrogen export by the Mississippi River. Proc. Natl. Acad. Sci., USA 105: 4513-4518.

Drew, M. C. (1975). Comparison of the effects of a localised supply of phosphate, nitrate, ammonium, potassium on the growth of the primary root system, and the shoot, in barley. New Phytologist, 75: 479-490.

Duan, Y. H., Zhang, Y. L., Shen, Q. R. and Wang, S. W. (2006). Nitrate effect on rice growth and nitrogen absorption and assimilation at different growth stages. Pedosphere, 16: 707-717.

Epstein, E. and Bloom, A. J. (2005). Sinauer Associates. In: Mineral Nutrition of Plants. Principles and Perspective. 2:p.172.

Ericsson, T. (1995). Growth and shoot: root ratio of seedlings in relation to nutrient availability. Plant Soil, 168169, 205-214

Forde, B. and Lorenzo, H. (2001). The nutritional control of root development. Plant and Soil, 232: 5168.

Frink, C. R., Waggoner, P. E. and Ausubel, J. H. (1999). Nitrogen fertilizer: retrospect and prospect. Proc. Natl. Acad. Sci., 96: 1175-1180.

Galloway JN, Townsend AR, Erismen JW, Bekunda M, Cai ZC, et al., (2008). Transformation of nitrogen cycle: Recent trends, questions and potential solutions. Science 320: 889-892.

Garg, A., Shukla, P. R. and Upadhyay, J. (2012). N2O emission of India: an assessment of temporal, regional and sector trend. Climate change, 110: 755-782.

Gerendas, J., Zhu, Z., Bendixen, R., Ratcliffe, 
R. G. and Sattelmacher, B (1997). Physiological and biochemical processes related to ammonium toxicity in higher plants. J Plant Nutr Soil Sci., 160: 239-251.

Giehl, R. F. H. and Wiren, N. V. (2014). Root nutrient foraging. Plant physiology, 166: 509-517.

Gioseffi, E., Neergard, A. de. And Schjoerring, J. K. (2012). Interactions between uptake of amino acids and inorganic nitrogen in wheat plants. Biogeosciences, 9: 1509-1518.

Gruber, B. D., Giehl, R. F., Friedel, S., and von Wirén, N. (2013). Plasticity of the Arabidopsis root system under nutrient deficiencies. Plant Physiol., 163: 161-179.

Gutiérrez, R. A., Lejay, L. V., Dean, A., Chiaromonte, F., Shasha, D. E. and Coruzzi, G. M. (2007). Qualitative network models and genome-wide expression data define carbon/nitrogen-responsive molecular machines in Arabidopsis. Genome Boil. 8:R7.

Ho, M.D., Rosas, J. C., Brown, K. M. and Lynch, J. P. 2005. Root architectural tradeoffs for water and phosphorus acquisition. Functional Plant Biology, 32: 737-748.

Johnson, J. M. F., Franzluebbers, A. J., Weyers, S. L. and Reicosky, D. C. (2007). Agricultural opportunities to mitigate greenhouse gas emission. Environ Pollut.,150: 107-124.

Jones, D.L., Owen, A. G. and Farrar, J. F. (2002). Simple method to enable the high resolution determination of total free amino acids in soil solutions and soil extracts. Soil Biol. Biochem., 34: 1893-1902.

Kamprath, E. J., Moll, R. H. and Rodriguez, N. (1982). Effects of nitrogenfertilization and recurrent selection on performance of hybrid populations of corn. Agronomy Journal, 74:955-958.

Kortbech-Olesen R (2000). Export opportunities of organic food from developing countries. In: World Organics, Agra Europa (London) Ltd., London.

Kronzucker, H. J., Britto, D. T., Davenport, R. and Tester, M. (2001). Ammonium toxicity and the real cost of transport. Trends Plant sci., 6: 335-337.

Krouk, G., Lacombe, B., Bielach, A., PerrineWalker, F., Malinska, K., Mounier, E., et al., (2010). Nitrate-regulated auxin transport by NRT1. 1 defines a mechanism for nutrient sensing in plants. Dev. Cell, 18: 927-937.

Lima, J. E., Kojima, S., Takahashi, H. and Wiren, N. (2010). Ammonium Triggers Lateral Root Branching in Arabidopsis in an AMMONIUM TRANSPORTER1;3-Dependent Manner. The Plant Cell, 22: 36213633.

Linkohr, B. I., Williamson, L. C., Fitter, A. H. and Leyser, H. M. O. (2002). Nitrate and phosphate availability and distribution have different effects on root system architecture of Arabidopsis. Plant J., 29: 751-760.

Lopez-Bucio, J., Cruz-Ramirez, A. and Herrera-Estrella, L. (2003). The role of nutrient availability in regulating root architecture. Curr. Opin. Plant Biol., 6: 280-287.

Lynch, J. P. (1995). Root architecture and Plant Productivity. Plant Physiology, 109: 7-13.

Lynch, J. P. (2011). Root phenes for enhanced soil exploration and Phosphorus acquisition: tools for future crops. Plant Physiol. 156: 1041-1049.

Mace, E. S., Singh, V., Oosterom, E. J., Hammer, G. L., Hunt, C. H. and Jordan, D. R. (2012). QTL for nodal root angle in sorghum (Sorghum bicolor L. Moench) colocate with 
QTL for traits associated with drought adaptation. Theoretical and Applied Genetics, 124: 97-109.

Mader, P., Fliessbach, D., Dubois, D., Gurist, L. Fried, P. et al., (2002). Soil fertility and biodiversity in organic farming. Science, 296: 1694-1697.

Manschadi, A. M., Hammer, G. L., Christopher, J. T., deVoil, P. (2008). Genotypic variation in seedling root architectural traits and implications for drought adaptation in wheat (Triticum aestivum L.). Plant and Soil, 303: 115-129.

Montzka, S. A., Dlugokencky, E. J. and Butler, J. H. (2011). Non CO2 greenhouse gases and climate change. Nature, 476: 43-50.

Mounier, E., Pervent, M., Ljung, K., Gojon, A., and Nacry, P. (2014). Auxin mediated nitrate signaling by NRT1.1 participates in the adaptive response of Arabidopsis root architecture to the spatial heterogeneity of nitrate availability. Plant Cell Environ.,37:162-174.

Nacry, P., Bouguyon, E. and Gojon, A. (2013) Nitrogen acquisition by roots: physiological and developmental mechanisms ensuring plant adaptation to a fluctuating resource. Plant Soil, 370: 1-29.

Oaks, A., Aslam, M. and Boesel, I. (1977). Ammonium and amino acids as regulators of nitrate reductase in corn roots. Plant Physiology, 159: 391-394.

Okamoto, M. and Okada, K. (2004). Differential responses of growth and nitrogen uptake to organic nitrogen in four graminaceous crops. Journal of Experimental Botany, 55: 1577-1585.

Owen, A. G. and Jones, D. L. (2001). Competition for amino acids between wheat roots and rhizosphere microorganisms and the role of amino acids in plant $\mathrm{N}$ acquisition. Soil
BiolBioche., 33: 651-657.

Panse, V.G. and Sukhatme, P.V. (1967). Statistical Methods for agriculture workers. India council for Agricultural Research, New Delhi.

Raab, T. K., Lipson, D. A. and Monson, R. K. (1999). Soil amino acid utilization among the Cyperaceae: plant and soil processes. Ecology, 80: 2408-2419.

Ramesh, P., Singh, M. and Subbha Rao, A. (2005). Organic farming: Its relevance to the Indian context. Current Science, 88: 561-568.

Raun, W. R. and Johnson, G. V. (1999). Improving nitrogen use efficiency for cereal production. Agronomy Journal, 91(3): 357-363.

Remans, T., Nacry, P., Pervent, M., Filleur, S., Diatloff, E., Mounier, E., et al., (2006). The Arabidopsis NRT1. 1 transporter participates in the signaling pathway triggering root colonization of nitrate-rich patches. Proc. Natl. Acad. Sci., 103: 1920619211

Roosta, H. R. and Schjoering, J. K. (2008). Root carbon enrichment alleviates ammonium toxicity in cucumber plants. J Plant Nutri.,31: 941-958.

Sandhu,N. K. A. Raman, R. O Torres, A. Audebert, A. Dardou, A. Kumar, A. Henry (2016): Rice root architectural plasticity traits and genetic regions for adaptability to variable cultivation and stress conditions. Plant Physiology: 171 (4) 2562-2576;

Saravitz, C. H., Chaillou, S., Musset, J., Raper Jr., C. D. and Morot-Gaudry, J. F. (1994). Influence of nitrate on uptake of ammonium by nitrate-depleted soybean: is the effect located in roots or shoots? J. Exp. Bot., 45:1575-1584.

Schortemeyer, M. and Feil, B. (1996). Root morphology of maize under homogenous or spatially separated supply of ammonium and nitrate at 
three concentration ratios. J. Plant Nutr., 19: 1089-1097.

Sharma K. M., Bardhan K. and Roy P (2017): Why organic farms do not give potential yield. Rashtriya Krishi. 12 (1):84-85

Sharma K.M and Bardhan K. (2017): Can high yielding varieties perform similarly in organic farms? Plant Achives. 17 (1): 675-680

Signora, L., De Smet, I., Foyer, C. H., and Zhang, H. (2001). ABA plays a central role in mediating the regulatory effects of nitrate on root branching in Arabidopsis. Plant J., 28: 655-662.

Tian, Q., Chen, F., Liu, J., Zhang, F., and Mi, G. (2008). Inhibition of maize root growth by high nitrate supply is correlated with reduced IAA levels in roots. J. Plant Physiol., 165: 942-951.

Tilman, D., Cassman, K. G., Matson, P. A., Naylor, R. and Polasky, S. (2002). Agricultural sustainability and intensive production practices. Nature, 418: 671-677.

Trachsel, S., Keppler, S. M., Brown, K. M. and Lynch J. P. (2013). Maize root growth angles become steeper under low $\mathrm{N}$ conditions. Field crop research, 140: 18-31.

Uga, Y., Okuno, K. and Yano, M. (2011). Dro1, a major QTL involved in deep rooting of rice under upland field conditions. Journal of Experimental Botany, 62: 2485-2494.

Vidal, E. A., Araus, V., Lu, C., Parry, G., Green, P. J., Coruzzi, G. M., et al., (2010). Nitrate-responsive miR393/AFB3 regulatory module controls root system architecture in Arabidopsis thaliana. Proc. Natl. Acad. Sci., 107:4477-4482.

Vitousek, P. M., Aber, J. D., Howarth, R. W., Likens, G. E. and Maston, P. A. (1997). Human alteration of the global nitrogen cycle: sources and consequences. Ecological application, 7: 737-750

Wang, M. Y., Siddiqi, M.Y., Ruth, T. J. and Glass, A. D. M.(1993). Ammonium uptake by rice roots. 1. Fluxes and subcellular distribution of $\mathrm{NH}^{+}-\mathrm{N}-13$. Plant Physiology, 103: 1249-1258.

Wang, X. and Below, F. E. (1992). Root growth, nitrogen uptake, and tillering of wheat induced by mixed-nitrogen source. Crop Sci., 32: 997-1002.

Wuebbles, D. J. (2009). Nitrous oxide: No laughing matters. Science, 326: 56-57.

Yamagata, M. and Ae, N. (1996). Nitrogen uptake response of crops to organic nitrogen. Soil Science and Plant Nutrition, 42: 389-394.

Yoshida, S., Forno; D. A., Cock, J. H. and Gomez, K. A. (1976). Laboratory Manual for Physiological Studies of Rice. The International Rice Research Institute.

Zhang, H., Jennings, A., Barlow, P. W., and Forde, B. G. (1999). Dual pathways for regulation of root branching by nitrate. Proc. Natl. Acad. Sci., 96: 6529-6534.

Zhu, J., Keppler, S. M., Brown, K. B. and Lynch, J. P. (2005). Topsoil foraging and phosphorus acquisition efficiency in maize (Zea mays). Funct. Plant Biol., 32: 749-762.

\section{How to cite this article:}

Jayeshkumar A. Bhabhor, Kirti Bardhan, Dhiraj P. Patel, Ajay V. Narwade and Harshad N. Chatrola. 2018. The Selective Vulnerability of Rice Root System Architecture to Organic and Inorganic Nitrogen. Int.J.Curr.Microbiol.App.Sci. 7(07): 1247-1265. doi: https://doi.org/10.20546/ijcmas.2018.707.150 